\title{
Exchange Rates, Monetary Policy, and Interest Rates in the Dominican Republic during the I990s Boom and New Millennium Crisis*
}

\author{
JOSÉ R. SÁNCHEZ-FUNG
}

Abstract. This article gives an account of the developments in the Dominican Republic's economy from the I 990 o boom to the crisis of the new millennium, focusing on the monetary and exchange rate dynamics behind that transition. It is argued that the liberalisation of interest rates in the I990s, together with an appreciated real exchange rate and weak bank supervision, led to the dollarisation of the banking system. These and other structural imbalances exacerbated the impact of a series of adverse shocks on the economy at the beginning of the millennium, including a banking crisis costing approximately 20 per cent of gross domestic product in 2003 .

\section{From crisis to boom and back}

During the I980s many developing countries, especially in Latin America, faced severe economic crises. This prompted widespread economic reform in the region, mostly undertaken in the late 1980 s and early i990s. ${ }^{1}$ An interesting example of these developments is the Dominican Republic (DR), a country that experienced some of the highest rates of GDP growth in the

José R. Sánchez-Fung is Senior Lecturer in the School of Economics, Kingston University, UK.

* An earlier version of this article was presented as a paper at the conference From 'Miracle' to Crisis to ... : Debating the Future of the Dominican Economy, held on 26 June 2004 at Baruch College, City University of New York (CUNY). I thank Héctor Cordero-Guzmán and Ramona Hernández for the invitation and financial support to participate in this event. I also thank, among others, Paul Beckerman and an anonymous referee of this journal for useful comments and suggestions on previous versions of the manuscript. At the time of writing, the author was Director of the Research Department, Central Bank of the Dominican Republic. However, the views expressed here are the author's, and do not necessarily reflect those of the Central Bank of the Dominican Republic or its Monetary Board.

1 See José Antonio Ocampo, 'Latin America's growth and equity frustrations during structural reforms,' Journal of Economic Perspectives, vol. I 8 (2004), pp. 67-88. 
region during the I990s on the back of Washington consensus-led reforms and the strong performance of its main trading partner, the USA, in that decade. ${ }^{2}$ The liberalisation of interest rates was thought of as one of the most remarkable of the reforms undertaken. ${ }^{3}$

Market-determined interest rates were expected to contribute to the deepening of the financial sector, and ultimately to the stability and growth of the reforming economies. In reality, however, high interest rates continued to prevail. Some authors have investigated the impact of the lifting of interest rate ceilings and of other financial liberalisation policies on interest rate spreads in selected Latin American countries during the I990s. ${ }^{4}$ They find that throughout the region high interest rate spreads have lingered as a common factor after the reforms. Amongst the reasons attributed to that outcome are high operating costs, non-performing loans, and country risk.

During the second-half of the I990s the DR also experienced a de facto dollarisation of its banking system. In 1996 the share in M2 (measured as currency plus current account and time deposits) of dollar-denominated deposits amounted to just over I.I per cent. In contrast, for 2002 this figure totalled 25 per cent. Mirroring this development, in 1996 the share of dollar loans in total $\mathrm{M}_{2}$ was $\mathrm{I} .2$ per cent, whereas it stood at 28 per cent at the end of 2002 . As a yardstick, these numbers are fairly close to Ecuador's before dollarisation.

Alongside interest rate liberalisation and escalating financial dollarisation, the I990s were a period of short-term macroeconomic stability and economic growth. ${ }^{5}$ Figure I displays output growth during the period $1_{96}{ }_{3}-2003$, that is, the recent democratic era in the DR. This figure highlights the fact that the growth rates observed in the late I 990 s are only bettered by those achieved in the I970s, a period that saw the implementation of an aggressive industrialization strategy. The i 970 s bonanza ended in the aftermath of the two oil price shocks that took place in that decade and affected economies across the world.

The Dominican economy's i 990 s boom also ended abruptly. The new millennium has brought several adverse shocks, including a major banking crisis costing over 20 per cent of GDP in 2003 , amidst adverse international

2 John B. Taylor, 'Monetary Policy and the Long Boom,' Federal Reserve Bank of St. Louis Review (November 1998).

3 Additionally, after I995, a series of financial reforms were undertaken. In particular, the banking system was allowed to lend in US currency. Thereafter the internal free flow of capital between US and DR currency contributed to the system's dollarisation. See Philip Young (ed.), The Dominican Republic: Stabilization, Structural Reform, and Economic Growth (Washington, DC, 2002), IMF Occasional Paper 206.

4 Phillip L. Brock and Liliana Rojas Suárez, 'Understanding the Behaviour of Bank Spreads in Latin America,' Journal of Development Economics, vol. 63 (2000), pp. I I 3-34.

5 See Young, The Dominican Republic: Stabilization, Structural Reform, and Economic Growth. 


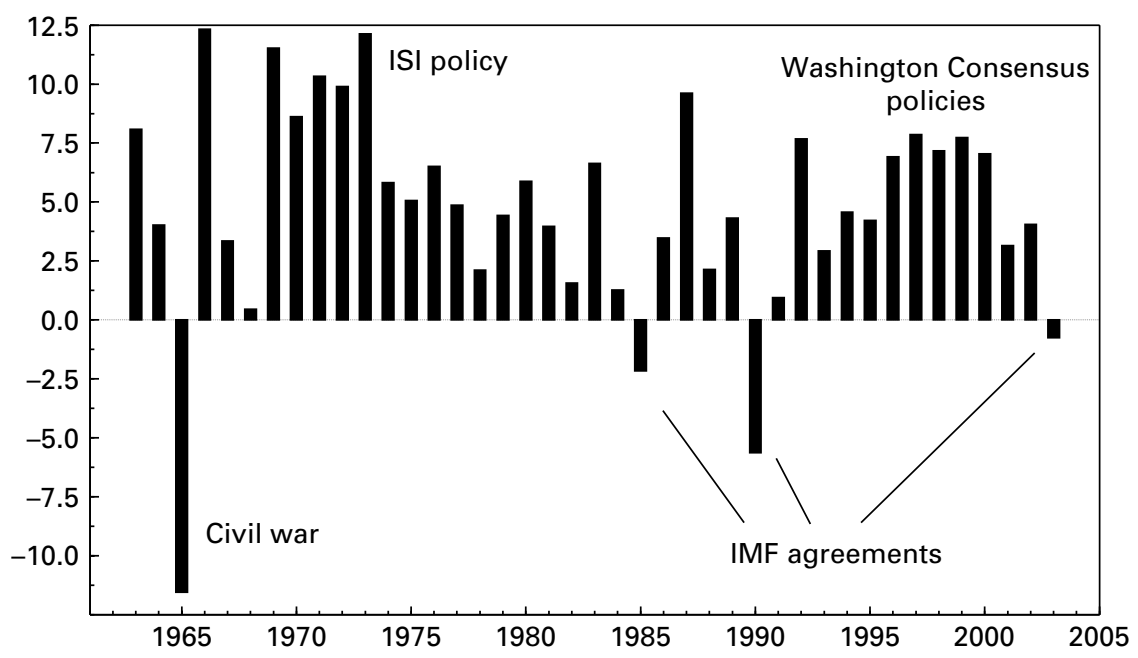

Fig. I. Dominican Republic: Real Output Growth (\%), 1963-2003. Source: Central Bank of the Dominican Republic.

conditions. Particular factors that affected the economy at the time were the slowdown in tourism after the irth September attacks on the USA, the reduced growth rate of the USA's economy, and higher petroleum import prices. ${ }^{6}$ The latter, exacerbated by the dollarisation of the Dominican economy, generated exchange rate instability, high inflation (see Figure 2), and weakened the effectiveness of monetary and fiscal (stabilisation) policies during $2003 .{ }^{7}$ As a result of these problems the DR signed a stand-by agreement with the IMF that was formally approved in August 2003.

It is worth noting that these developments had a negative impact on the overall performance of the economy and, critically, are reflected in the prices of the four Dominican government bonds traded in the international markets. This can be clearly perceived in Figure 3, which shows the prices of the Dominican bonds (shown in reverse chronological order) substantially dropping in May 2003 after the public denunciation of a major bank fraud. ${ }^{8}$ For a low middle-income economy such as the DR accessing the international markets to obtain resources at reasonable rates is of paramount

6 See 'Dominican Republic in Crisis,' The New York Times, 29 Dec. 2003.

7 Remarkably, in the DR fiscal policy has tended to be pro-cyclical rather than contra-cyclical, which is contrary to what economic theory suggests. However, this has been a common factor across Latin American countries. See, for instance, the work of Michael Gavin and Roberto Perotti, 'Fiscal Policy in Latin America,' in Ben S. Bernanke and Julio J. Rotemberg (eds.), NBER Macroeconomics Annual 1997, pp. i I-7 I.

8 The bonds are a PDI, discounted bond (DISC), and two more recently issued sovereign bonds (Bond 06 and Bond I 3 ). 


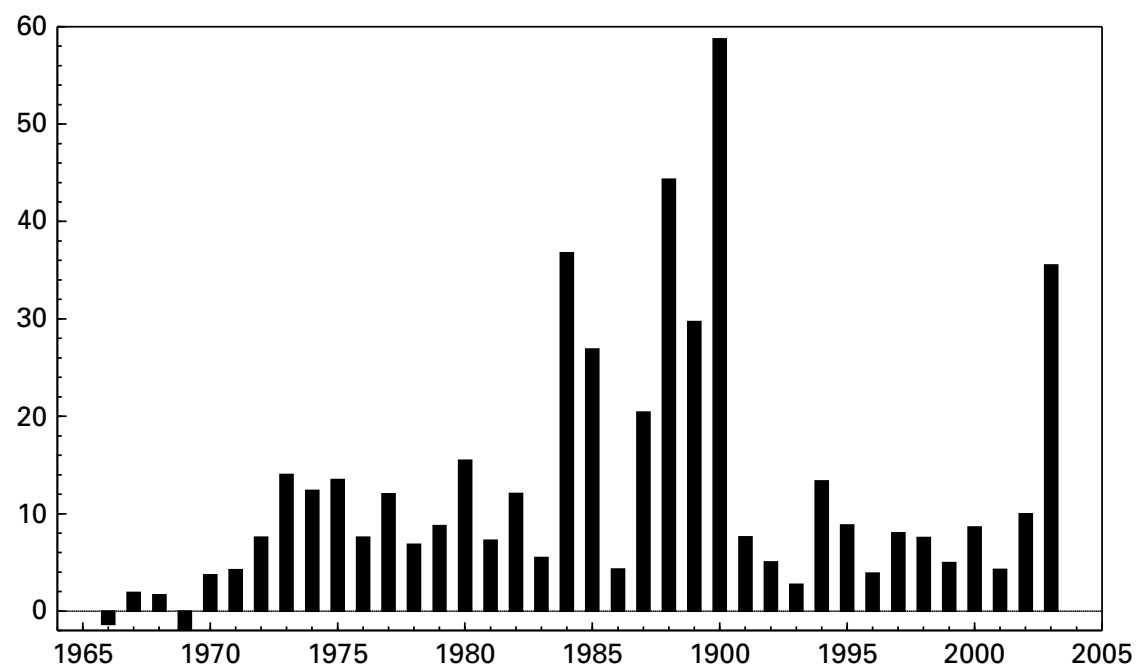

Fig. 2. Dominican Republic: Inflation Rate (\%), 1966-2003. Source: Central Bank of the Dominican Republic.

importance, and for this to be possible internal stability is vital. ${ }^{9}$ In this regard we should bear in mind that the adverse developments in the prices of the DR's foreign bonds are largely due to bondholders' perception of the likelihood of an eventual sovereign default.

\section{Explaining the transition: A synopsis on a view from the monetary sector}

Within the setting just sketched at least two pressing questions are of interest. Firstly, during the I990s, how did interest rate liberalisation affect the behaviour of the exchange rate market? This matter is of interest due to the role played by the exchange rate and interest rates in policymaking and in the wider policy reforms in developing economies. ${ }^{10}$ We should recall that there is a link between the interest rate differential between Dominican peso and US dollar financial instruments, and the exchange rate via the uncovered interest parity hypothesis. ${ }^{11}$

${ }^{9}$ However, Paolo Mauro, Nathan Sussman and Yishay Yafeh, 'Emerging Market Spreads: Then Versus Now,' Quarterly Journal of Economics, vol. I 17 (2002), pp. 695-733, argue that country-specific events play a smaller role on developments in emerging markets bonds during $199^{2-2000}$ than during $1870-1913$, two periods of comparable activity in this market.

10 Guillermo A. Calvo and Carmen M. Reinhart, 'Fear of Floating,' Quarterly Journal of Economics, vol. I I7 (2002), pp. 379-408.

11 See, for example, Robert P. Flood and Andrew K. Rose, 'Uncovered Interest Parity in Crisis,' IMF Staff Papers, vol. 49 (2002), pp. 25 2-66. 


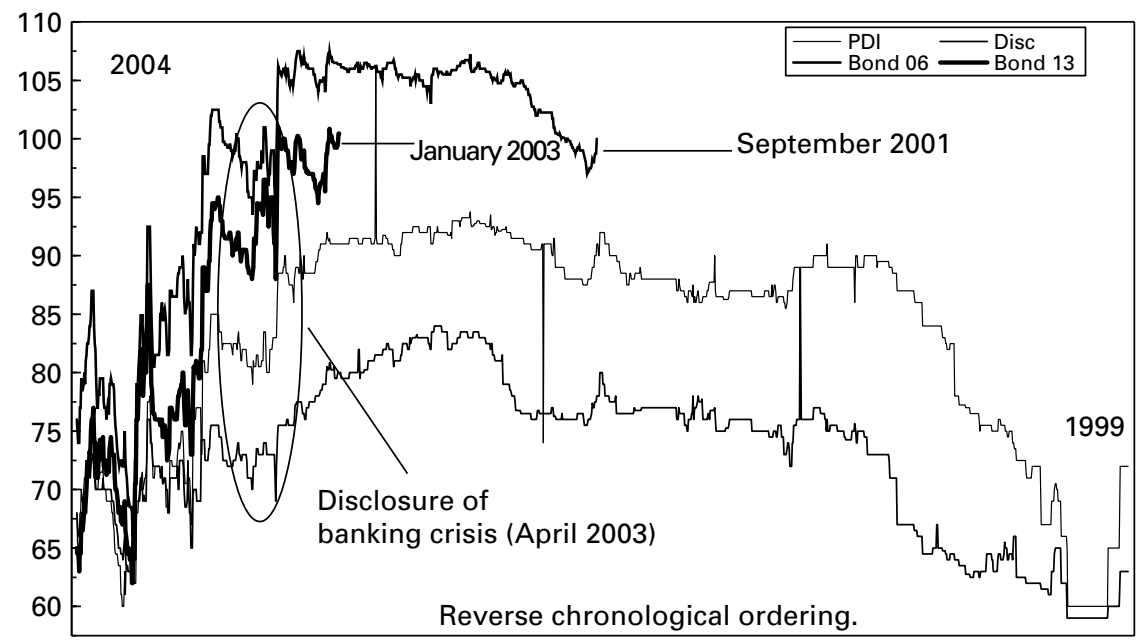

Fig. 3. Dominican Republic: Daily Government Bonds Prices, 1999-2003. Source: Bear, Stearns \& Co. Inc.

Looking back to the beginning of the twentieth century we find that the DR allowed the US dollar to circulate freely as an acceptable medium of payment - an interesting early example of dollarisation in Latin America. Subsequently, in the I930s the DR pegged its currency to the US dollar after Great Britain and the USA abandoned the Gold Standard. ${ }^{12}$

The formal history of the country's own currency can be traced back to the foundation of the Central Bank of the Dominican Republic, and the introduction of the Dominican Peso (DR\$) in 1947. Of the struggles that the Dominican peso has endured since its introduction, Dornbusch and Giovannini note that,

Interestingly $\ldots$ in the case of the Dominican Republic, a one-to-one fixed exchange rate was made a provision of the constitution. And even that was not enough to stop fiscal and monetary policies ultimately inconsistent with the fixed exchange rate. ${ }^{13}$

As suggested by Dornbusch and Giovannini, through modern democratic times (that is, after the end of a 30-year dictatorship in i961 and the subsequent political and social struggle that culminated with a civil war in 1965) four major exchange rate regimes can be identified in the DR. It is worthy of note that in the regimes to be outlined below a parallel market for foreign

12 See Victor Bulmer-Thomas, The Economic History of Latin America since Independence (Cambridge, 1994).

13 Rudiger Dornbusch and Alberto Giovannini, 'Monetary Policy in the Open Economy,' in Benjamin M. Friedman and Frank H. Hahn (eds.), Handbook of Monetary Economics, vol. 2 (The Netherlands, 1990), pp. I 23 I-303. 
exchange existed alongside the official market. ${ }^{14}$ Thus from the mid-i 960 a multiple exchange rate system has prevailed in the DR.

The salient features of this exchange rate system from the ig6os to the beginning of the new millennium are:

(1) Mid-r960s-r984: fixed official exchange rate regime, which led to a series of agreements with the International Monetary Fund in January i 983 , September i 984 , and January i 985 .

(2) I985-July I988: a period opened by the first devaluation of the official exchange rate in January 1985 , its flotation, imposition of restrictions on the foreign exchange market by the Central Bank of the Dominican Republic, and closed by the re-fixing of the official rate in July i 988.

(3) July I988-August I991: a phase comprising the re-fixing of the official exchange rate and the stabilisation agreement signed with the International Monetary Fund in August i 991.

(4) September 1991-2003: ranges from the I99I agreement with the IMF to the year 2003, when the official exchange rate was abandoned, in line with the new Monetary \& Financial Law of December 2002.

The transition pattern from periods (I) to (2) to (3) has been characterized as a stylized fact in the literature. ${ }^{\mathbf{1 5}}$ Some authors have singled out the events that are usually observed after a crisis involving a fixed exchange rate regime. According to Garber and Svensson:

A salient feature of fixed exchange rate regimes is their inevitable collapse into some other policy regime. The collapse is frequently spectacular-extraordinary large interventions into foreign exchange markets and losses by central banks ... and a period of turbulent floating in a transition to the new regime. ${ }^{\mathbf{1 6}}$

The second major question that arises in the scenario depicted hitherto is whether during the I990s and early 2000 s economically sensible money demand functions can be identified for the DR's economy, and if they were effectively used in the design and monitoring of monetary policy. It would be understandable if the crucial events outlined above imply changes in the structure of the economy, in general, and particularly key economic relations such as money demand.

In the DR monetary policy is based on a monetary programme within which money demand plays a vital role. This contrasts to how monetary policy operates in more advanced economies, such as the US and the UK,

14 See José R. Sánchez-Fung, 'Efficiency of the Black Market for Foreign Exchange and PPP: The Case of the Dominican Republic,' Applied Economics Letters, vol. 6 (1999), pp. 173-6.

15 Peter M. Garber and Lars E. O. Svensson, 'The Operation and Collapse of Fixed Exchange Rate Regimes,' in Gene M. Grossman and Kenneth Rogoff (eds.), Handbook of International Economics, vol. 3 (The Netherlands, I995), pp. I647-88.

16 Ibid. 
where the interest rate is the main policy instrument. ${ }^{17}$ For this reason looking into the behaviour of money demand in the last decade can help understand the broader monetary dynamics driving the economy during that period. Nonetheless, the reader should note that from the late i990s a transition to a monetary policy that operates via interest rates has taken place.

\section{Exchange rates and interest rates}

This section attempts to determine the impact of interest rate liberalisation on exchange rate expectations in the Dominican Republic (DR), as this is one of the key financial developments leading up to the new millennium crisis. Topical research on the matter employs a nested purchasing power parity, random walk, and uncovered interest parity specification that facilitates the recovery of the fundamentals behind the exchange rate expectations formation mechanism. ${ }^{18}$ This reveals that the most significant driver of exchange rate expectations is the interest rate differential between the DR and its main trading partner - the United States of America. A basic explanation of this somehow puzzling fact is that higher interest rates attract capital under certain conditions, but also can raise questions about whether the system can actually pay these higher interest rates.

Although challenging to standard economic theory, these results are in harmony with previous analysis of the performance of uncovered interest parity (UIP) in crises. ${ }^{19}$ The study in question concludes that exchange rate depreciation in 23 developed and developing countries generally followed interest rate differentials. The authors also point out that UIP seems to work better in times of crisis, which also seems to be true for the DR. Furthermore, their investigation unveils a close relationship between the actual and expected exchange rates calculated using the model. An interesting feature is the convergence of expectations towards the actual exchange rate after the introduction of an IMF stand-by agreement in I991. Moreover, after 1995 , and the substantial reforms introduced in the banking system an equilibrium correction pattern emerges - consistent with the fear of floating argument of interest rate adjustments. ${ }^{20}$ Basically, the fear of floating idea brings out the fact that many countries are reluctant to allow their currencies to float freely, even when they state the intention of so doing.

17 See Michael Woodford, Interest and Prices (Princeton, 2003).

18 José R. Sánchez-Fung and Peter A. Prazmowski, 'PPP, Random Walks, and UIP after Interest Rate Liberalization in a Small Developing Economy,' Economics Bulletin, vol. 6 (2004), pp. I-7. ${ }^{19}$ Flood and Rose, 'Uncovered Interest Parity in Crisis,' pp. 25 2-66.

20 Calvo and Reinhart, 'Fear of Floating,' pp. 379-408. 
By the beginning of the new millennium several internal and external shocks, including the September i a attacks and the collapse of one of the DR's major commercial banks in 2003, contributed to the widening of the interest rate gap between Peso and Dollar denominated instruments. This led to a corresponding jump in economic agents' expectations, and drift away from the long run equilibrium between the exchange rate, interest rates, and internal and external prices. A line of argument might be that the mid-i 990 s reforms aimed at enhancing capital mobility and full access to foreign currency lending exacerbated this outcome. Arguably, this has not been helped by the fact that the DR's prudential regulation of the banking system is poor, and therefore the economy was not ready for such reforms.

\section{The role of money and monetary policy}

From structural factors the paper moves on to policy concerns. A good starting point to understand the role played by money and monetary policy is the study of a simple, textbook, money demand relationship. A standard money demand function relates real monetary balances $\left(\frac{M}{P}\right.$, where $M$ is a monetary aggregate and $P$ a price index) to a scale variable (output $Y$ ), and a measure of the opportunity cost of holding money (interest rate $R$ ) that can be written as

$$
\frac{M}{P}=f(\stackrel{+}{Y}, \stackrel{-}{R})
$$

The equation shows that output is expected to have a positive and the interest rate a negative impact on the demand for real monetary balances. For a small open economy like the DR, the analysis can also account for the impact of the foreign interest rate on the demand for money. A study of money demand in the I 990 s and early 2000 s using monthly economic time series data, generates economically and statistically sensible results. ${ }^{21}$ Notably, they are in line with theoretical predictions for the open economy, and the findings of previous studies. ${ }^{22}$

A crucial result arising from this analysis is the positive, long run, impact of the interest rate differential between peso and dollar interest rates on broad money $\left(\mathrm{M}_{2}\right)$. As highlighted above, a de facto financial dollarisation took place in the DR from I996, from which point dollar denominated bank

${ }^{21}$ See José R. Sánchez-Fung, 'Modelling Money Demand in the Dominican Republic,' School of Economics discussion paper, Kingston University, 2004.

22 Alan Carruth and José R. Sánchez-Fung, 'Money Demand in the Dominican Republic,' Applied Economics, vol. 32 (2000), pp. I439-49. Oral Williams and Olumuyiwa Adedeji, 'Inflation Dynamics in the Dominican Republic,' (Washington, DC, 2004), IMF Working paper 04/29. 
operations as a share of $\mathrm{M}_{2}$ started progressively to increase. So, particularly during the sample period under study, the positive coefficient on the interest rate differential could actually be reflecting a structural risk premium that triggered a flight from peso to dollar-denominated deposits. The situation was not helped by the newly permitted dollar bank operations.

The mechanism described above would be more realistic if international parity conditions held. In fact, the most significant driver of exchange rate expectations in the DR from the mid-I990s is the interest rate differential between the DR and the USA. This means that an increase in the interest rate differential between these two economies, ceteris paribus, depreciates the domestic currency, probably reflecting the risk embodied in this gap.

At least part of the story could be seen as a by-product of the fact that economic agents tried to arbitrage the differential between dollar- and pesodenominated bank operations after 1996 , in an attempt to hedge against the currency risk that is typical of small developing economies. Banking regulation allowed most of this arbitrage to be internalised by the domestic banking system, but an appreciated exchange rate throughout the mid-i 990 o also contributed to the phenomenon at hand. A real appreciation implies that agents feel richer than they are, and the country's exports are penalised. The I 990 appreciation can be seen in Figure 4, which shows the history of the real exchange rate of Dominican Republic pesos per United States dollars from 1970 to 2003.

The analysis of money demand for the DR also reflects a fine-tuned monetary policy stance at the end of the I990s, which, however, fades thereafter. This development might well emerge from a time-consistency problem underlying the monetary policy credibility success achieved at the end of the last decade. ${ }^{23}$ It can be argued that the country's frail monetary, fiscal, and financial supervision institutions could not underwrite a sustained performance as the one observed in the i 990 s.

\section{Challenges for monetary policy: Understanding the behaviour of the interbank market}

Now that two of the key macro-monetary elements in the Dominican Republic's I990s boom and new millennium crisis - the exchange rate and money - have been assessed, we can proceed to consider those factors that should rise to prominence as monetary policy institutions become more efficient. As noted earlier, inter-bank interest rate determination and volatility are of key importance in the day-to-day monitoring of monetary policy. Some economies (e.g., Australia, Canada, and New Zealand) target the

${ }^{23}$ Finn E. Kydland and Edward C. Prescott, 'Rules Rather than Discretion: The Inconsistency of Optimal Plans,' Journal of Political Economy, vol. 85 (I977), pp. 473-9I. 


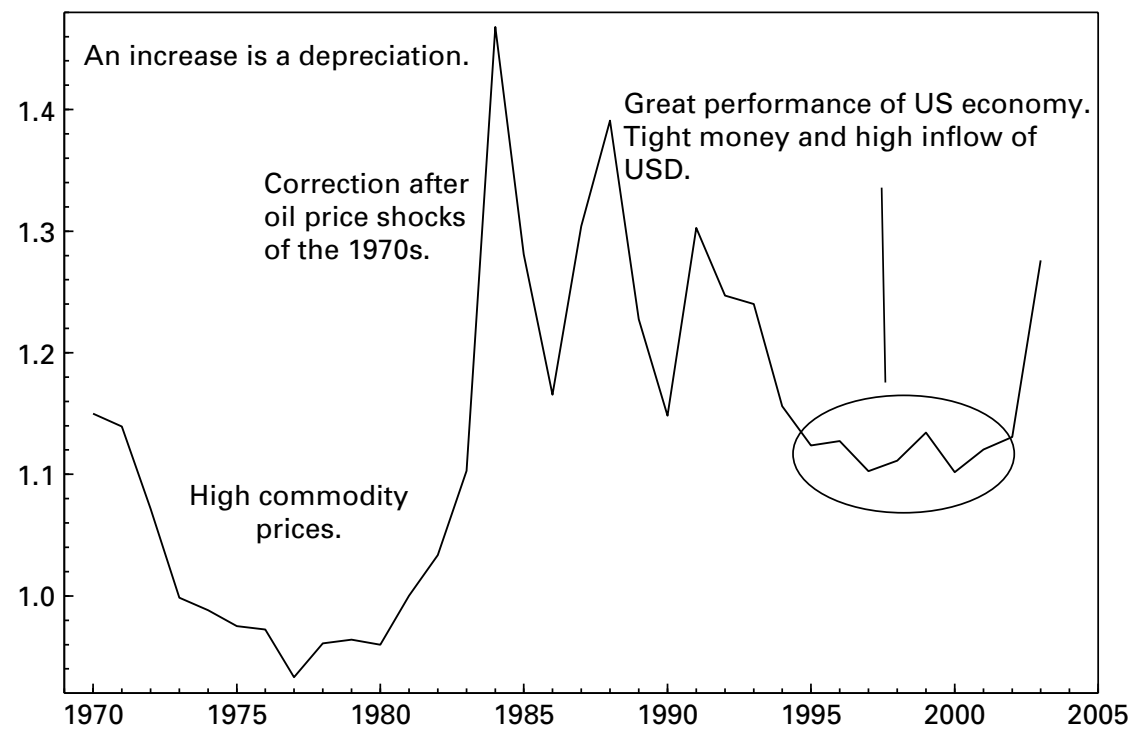

Fig. 4. Dominican Republic: Real Exchange Rate DoP/US\$, 1970-2003. Source: Central Bank of the Dominican Republic, and author's calculations.

short-end of the yield curve as a policy strategy, therefore enhancing the role of interbank rates and the money market. ${ }^{24}$

In less developed systems - where weaker institutions, lack of central bank independence, and a paucity of monetary instruments can make monetary control extremely difficult - a key step in developing an effective monetary policy strategy is the construction of a mechanism to affect short-term interest rates. For that reason understanding inter-bank interest rate determination assumes paramount importance for an efficient monetary policy implementation. The future success of monetary policy in the DR will depend on the monetary authorities' ability to have an effect on developments in the money market.

However, the success of monetary policy implementation also demands the existence of exchange rate, government securities, and equity markets that can make the financial system more liquid. Ideally, these markets should be fully accessible to foreign investors, but only after strong and independent supervision institutions are in place. With those provisos in mind, we can highlight some features of the interbank market.

In the DR - a country in which the banking system operates under a fractional reserve system - studying developments in the inter-bank market

24 Alessandro Prati, Leonardo Bartolini and Giuseppe Bertola, 'The Overnight Interbank Market: Evidence from the G-7 and the Euro Zone,' Journal of Banking and Finance, vol. 27 (2003), pp. $2045-83$.

\section{CAMBRIDGE JUURNALS}




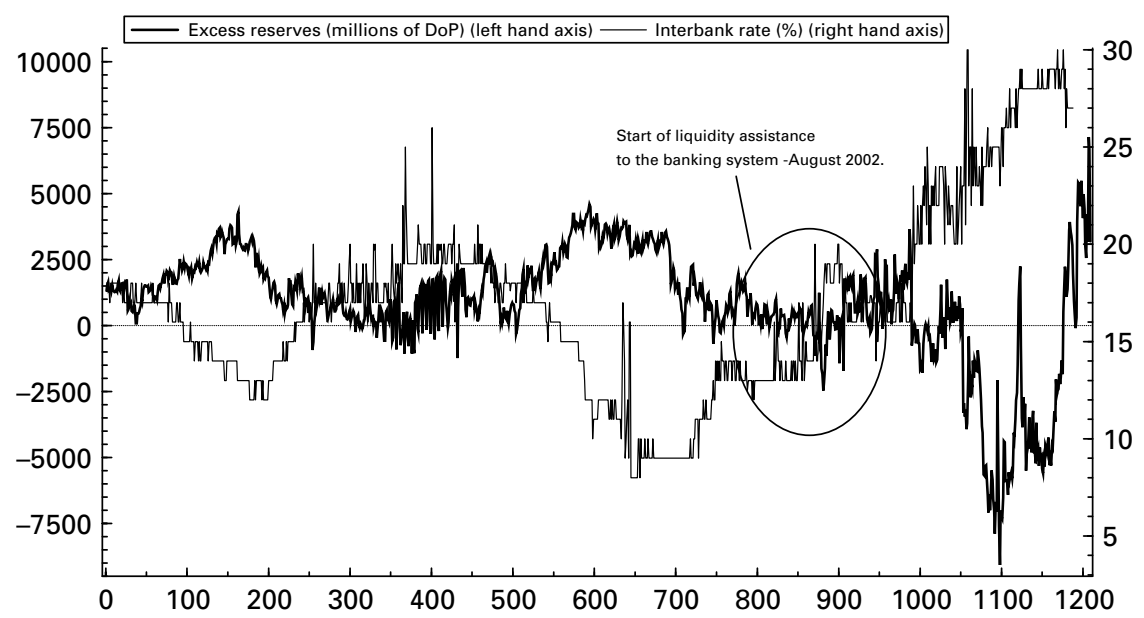

Fig. 5. Dominican Republic: Daily Interbank Market, 1999-2003. Source: Central Bank of the Dominican Republic.

is of particular interest in order better to understand some of the ramifications from the severe banking crisis that affected the economy during 2002-2003. As a preliminary insight into that market, Figure 5 plots daily time series of aggregate excess banking system reserves and inter-bank rates for the period ranging from January 1999 to November 2003. This graph reveals the expected negative relationship between the variables in question.

More technical econometrics analysis of the topic has advanced our understanding on the link between inter-bank rates and excess reserves in the $\mathrm{DR}^{25}$ One key finding is that, on average, positive shocks on inter-bank interest rate volatility have a smaller impact than negative ones. More interesting still is the fact that volatility indicators of the interbank market show an increased significance roughly from August 2002.

Remarkably, at that point the monetary authorities began to provide liquidity assistance to the main troubled bank, BANINTER (see Figure 5). ${ }^{26}$ So, apparently in times of financial stability positive or negative shocks have similar effects. In contrast, during banking crisis negative impacts generate larger volatility of inter-bank rates. That is, the link between interbank rates and reserves is asymmetric.

These finding have important implications for monetary policy design and operation. Since monetary authorities bring into play inter-bank rates to send

25 See José R. Sánchez-Fung, 'Daily Interbank Rates, Policy Intervention, and Volatility in a Banking Crisis,' unpubl. paper, Central Bank of the Dominican Republic, 2004.

26 Two further banks later went bust: BANCREDITO and Banco Mercantil. 


\section{José R. Sánchez-Fung}

signals to the rest of the term structure of interest rates, it is of great importance to monitor excess reserves and the price of funds in the interbank market. If monetary policy is to be successful, any surge in volatility arising from shocks to these variables, such as reserves deficiencies generated by troubled banks, should be curtailed.

At least provisionally, it can be concluded that asymmetric volatility indicators prove valuable as early warning indicators in the day-to-day monitoring of the DR's inter-bank market. However, very much more remains to be learned from this and other related markets, before monetary policy in the DR can be fully operational around it.

\section{Conclusion}

During the I990s the Dominican Republic experienced extraordinary rates of economic growth on the back of structural reforms and the impressive performance of its main trading partner, the USA, during that decade. This came to a halt after the USA's dotcom bubble burst and a major domestic banking crisis. This paper has attempted to recount the crisis experienced by the DR in the new millennium, paying particular attention to the economy's exchange rate and monetary dynamics during the period in question.

The article has indicated some of the major challenges that lie ahead, including reforming monetary policy implementation and institutions. ${ }^{27}$ In particular, it has highlighted the importance of understanding how the DR's money market works, and how it could be made more operational. This understanding is crucial if monetary policy is to become more effective in the future, because of the prominence of this market in affecting the term structure of interest rates and the operation of the transmission mechanism of monetary policy.

${ }^{27}$ See José R. Sánchez-Fung, 'Reglas monetarias, metas de inflación y sus aplicaciones potenciales en el diseño y la ejecución de la política monetaria en la República Dominicana,' Monetaria, vol. 27 (2004), pp. 29I-323, for an analysis on the potential future directions for monetary policy design and implementation in the DR. 